\title{
The Study of Family Planning Interpersonal Communication/Counseling in Contraceptive Use
}

\author{
Sari Kistiana ${ }^{1 *}$, Margareth Maya Naibaho ${ }^{1}$, Mario Ekoriano ${ }^{1}$, Desy Nuri \\ Fajarningtiyas ${ }^{1}$, Diah Puspita Sari ${ }^{2}$ \\ ${ }^{1}$ Research and Development Center of Family Planning and Prosperous Family, National Population and Family \\ Planning Board Jakarta, Indonesia \\ ${ }^{2}$ Research and Development Center of Family Planning and Prosperous Family, National Population and Family \\ Planning Board Surakarta, Indonesia \\ "Corresponding Author. Email: sarikistiana@gmail.com
}

\begin{abstract}
The contraceptive discontinuation rate among women age 15-49 increased from 21 percent in 2002-2003 to 29 percent in 2017. The absence of family planning counseling is considered as one of the factors associated with contraceptive discontinuation. The aim of this study was to assess the implementation of family planning interpersonal communication/counseling conducted by midwives. Data were collected in South Sumatera and West Kalimantan, with a combination of qualitative and quantitative descriptive methods. Family planning (FP) counseling should be conducted prior to contraceptive use. Observation of client-provider interactions indicated that all the clients who came to the health center for family planning services have received counselling. However, the counselling was not yet appropriate, it was not in accordance with guiding principles of counselling and there are several aspects of micro counselling skills that are not implemented during counselling. The study also concluded that there were significant differences in knowledge regarding the contraceptive methods between clients who received interpersonal communication/counseling and who were not. Efforts should be made to ensure interpersonal communication/counseling implemented prior to contraceptive use; the using of the Decision-Making Tool for family planning clients and providers is highly suggested, so that interpersonal communication/counseling is based on the key principles of good counselling.
\end{abstract}

Keywords: interpersonal communication, counseling, family planning, contraceptive use

\section{INTRODUCTION}

Family Planning (FP) is about deciding how many children couples choose to have and when they want to have them (timing of pregnancies and birth spacing). The focus on quality of care in family planning has drawn attention to the counseling for family planning. The role of family planning counselling is to support the woman and her partner in choosing the method of family planning that best suits them and to support them in solving any problems that may arise with the selected method. If a woman, preferably with her partner, is able to make an informed choice, she is more likely to be satisfied with the method chosen and continue its use.

The Government of Indonesia through its regulation ensure that contraceptive use in family planning should be preceded by family planning counseling [1]. The Counseling of family planning in Indonesia known as Interpersonal Communication/Counseling (IC/C). IC/C refers to a process of direct interaction, a two-way communication between a skilled provider, bounded by code of ethics and practice, and clients. It aims to help clients to choose and employ family planning methods that suit them by providing complete and accurate information about all appropriate and available options of contraceptive methods [2]. Information given to clients includes information about the range of methods available, their scientifically documented contraindications, advantages and disadvantages, details on how to use the method selected, its potential side effects and what to do when the side effects occurred [3]. The Decision-Making Tool (DMT) for family planning is a flip chart tool to help providers giving IC/C effectively.

The counseling provided by a family planning program plays a key role in contraceptive uptake and its continuation and is essential for ensuring informed and voluntary decision making. Since 2013, the Government (National Population and Family Planning Board) has been trained 20.403 providers from 34 provinces in family planning ICC training. In spite of government initiative to scale up counselling training, the contraceptive discontinuation rate among married women age 15-49 continuously increased from 21 percent in 2002-2003 to 26 percent in 2007, experienced one percent rise in 2012 (27 percent), and finally at 29 percent in 2017 [4]. The main reasons for contraceptive discontinuation included fear about side effects or health concern (30 percent) and the desire to become pregnant ( 30 percent). 
Studies conducted worldwide have repeatedly shown that the quality of family planning counselling is weak because providers' skill is inadequate. This is not surprising since the skill-building component of training for counselors is usually kept short and sometimes is even skipped [5]. Counseling training traditionally focuses on addressing the needs of the new clients, whilst clients differ, their situation differs, and they need different kinds of help [6]. The communication is usually one way and clients are not prepared for what side effects to expect or for what to do when those side effects occur.

Despite published research on the study of family planning quality of care in Indonesia, relatively little is known regarding the quality of family planning counseling in Indonesia. Various other studies have analyzed general family planning services rather than focusing specifically on counseling $[7,8,9]$. The present study, therefore, aimed to assess the implementation family planning interpersonal communication/counselling conducted by midwives at the governmental and private health centers.

\section{METHOD}

The study adopted the quality of care of Judith Bruce as the theoretical framework in this study [10]. The concept used for this study was the system approach, comprise of input, process and output components. For the input, the analysis was focused on supporting resources such as policy, equipment and facilities, availability of contraceptive methods, human resources, and local norms or culture.

For the process component, the study analyzed on how IC/C was carried out at the health center, including midwives' experience in family planning service, mechanism during FP IC/C, the coverage of FP methods offered, situation during FP IC/C and the duration of FP IC/C. The output component consists of client' acceptance of FP, clients' knowledge, attitude and practice of contraception.

This study was conducted in Palembang City and Banyuasin District of South Sumatera and Singkawang City and Menpawah District of West Kalimantan, which has the highest number of trained midwives in FP IC/C. For each selected district one sub district Primary Health Care (PHC).and one private midwifery clinic in sub district level were selected.

The study used qualitative and quantitative descriptive methods. Qualitative approach, such as document analysis, direct observation, group interview and in-depth interviews have been employed to understand the nature of FP IC/C from ten trained FP midwives, FP program manager and policy makers. A semi-structured topic guide with an openended question for group and in-depth interviews was developed to explore input and process component. Direct observation was on facilities and equipment, also the practice of FP IC/C given at the health center. A total 10 trained midwives from eight health center were selected purposively, with work related to FP IC/C practice. All interviews were digitally audio recorded and the data from in-depth interview transforming into a transcript and then were processed using content analysis. The transcript was divides into categories that related to the aim of this study.
Whereas quantitative data of 264 clients, were used to examine contraceptive knowledge, attitude and practice. The target sample included clients who visited the selected health center to obtain FP services in the past year including those first-time users, returning clients and those seeking contraceptive advice. Univariate analysis was performed to examine the frequency distribution of each variable from the quantitative data. Ethical approval for this research granted from ethics committee of Population and Family Planning Board.

\section{RESULTS AND DISCUSSION}

\section{Qualitative}

Four group interview revealed that there is no specific policy at the provincial and district level regarding FP IC/C. All the policies and regulations are referring to national regulation on FP IC/C (Table 1). "The policy implemented at provincial level is in line with the central policy (Central policy), that counselling must be conducted prior to family planning services are carried out." (GI02, FP policy maker).

According to the law and regulations, contraceptive use should be preceded by counselling so that clients could decide to choose contraceptive method without coercion and that best suits them. The information given during counselling must be complete, accurate and accessible. Whilst the use of DMT for FP during counselling only suggestion, so that providers could perform standardize counselling.

Almost all PHCs developed an SOP for counselling in family planning services, only in Sungai Pinyuh the SOP was for general counselling services, include FP. No SOP for contraceptive counselling was found at all private midwifery clinics.

Table 1. Law and Regulations on Family Planning ICC

\begin{tabular}{|c|c|c|}
\hline Law and Regulations & Article & Contain \\
\hline $\begin{array}{l}\text { Law Number } 52 \text { of } \\
2009 \text { on Population and } \\
\text { Family Development } \\
{[11]}\end{array}$ & 23 & $\begin{array}{l}\text { Improving access and } \\
\text { counselling quality } \\
\text { through the provision of } \\
\text { complete, accurate and } \\
\text { accessible information on } \\
\text { side effects, } \\
\text { complications and } \\
\text { contraceptive failure, } \\
\text { including its benefit in } \\
\text { preventing sexually } \\
\text { transmitted infections }\end{array}$ \\
\hline 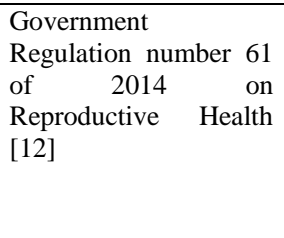 & 22 & $\begin{array}{l}\text { The right for everyone to } \\
\text { choose contraception } \\
\text { without coercion by } \\
\text { considering age, parity, } \\
\text { number of children, } \\
\text { health conditions and } \\
\text { religious norms }\end{array}$ \\
\hline $\begin{array}{l}\text { Regulation of The } \\
\text { Minister of Health of } \\
\text { The Republic Indonesia } \\
\text { No.97 of } 2014 \text { on Pre } \\
\text { Pregnancy, Pregnancy, } \\
\text { Post Pregnancy Health } \\
\text { Services, Contraceptive }\end{array}$ & 20 & $\begin{array}{l}\text { Contraceptive use must } \\
\text { be preceded by } \\
\text { counselling and informed } \\
\text { consent. Counselling is } \\
\text { IEC on contraceptive } \\
\text { methods completely and } \\
\text { sufficiently so that }\end{array}$ \\
\hline
\end{tabular}




\begin{tabular}{|c|c|c|}
\hline $\begin{array}{l}\text { Services and Sexual } \\
\text { Health Services [1] }\end{array}$ & & $\begin{array}{l}\text { patients could decide to } \\
\text { choose contraceptive } \\
\text { methods that best suits } \\
\text { them }\end{array}$ \\
\hline $\begin{array}{l}\text { Regulation of The } \\
\text { Minister of Health of } \\
\text { The Republic Indonesia } \\
\text { No.97 of } 2014 \text { on Pre } \\
\text { Pregnancy, Pregnancy, } \\
\text { Post Pregnancy Health } \\
\text { Services, Contraceptive } \\
\text { Services and Sexual } \\
\text { Health Services [1] }\end{array}$ & $\begin{array}{l}\text { II } \\
\text { Attachment }\end{array}$ & $\begin{array}{l}\text { In counselling, providers } \\
\text { can use DMT for FP. FP } \\
\text { DMT help providers in } \\
\text { conducting standardize } \\
\text { counselling and at the } \\
\text { same time assist client to } \\
\text { be more participatory and } \\
\text { helps them make } \\
\text { decisions about FP } \\
\text { method }\end{array}$ \\
\hline
\end{tabular}

The Training on IC/C using DMT for FP was held every year since 2012 until 2017 in South Sumatera, the total number of trained provider 1.714 from almost all districts (except Panukal Abab Lematang Ilir District and Musi Rawas Utara District). While there were 744 providers from all districs had been trained in West Kalimantan from year 2013 until 2017. All the training was conducted by Provincial Representative of National Population and Family Planning Board (NPFPB).

DMT for FP is the one and only tool to assist standard FP counselling, usually after the FP IC/C training, providers received a certificate of attendance and DMT. Generally, there is one DMT at each health center, only one private midwifery clinic has no DMT. To carry out FP IC/C, none of the health center has a separate counselling room. All the IC/C conducted at the same room as for mother and child health service.

Negative myths and misconceptions about family planning are a barrier to modern contraceptive use. Regarding rumors concerning contraceptive, from 264 clients who has visited health facilities to obtain FP services in the past year, about 72 percent has heard rumors about contraceptives and found that 25 percent of them believed that the rumors are true.

"There is a rumor about contraception in this neighborhood, according to patient that IUD can move toward the heart." (IDI01, Midwives).

Ten midwives were interviewed: seven sub district PHC midwives and three private midwives. Their experience in family planning service ranged from just over 6 years to 45 years and all of them can provide all contraceptive methods except permanent ones (tubal ligation and vasectomy). In a month, average FP services provided by these midwives range from 15 to 70 services, dominated by oral contraception and injection. Almost all midwives (86 percent) had received training on Contraceptive Technology Update (CTU).

\section{Quantitative}

Quantitative data from 264 clients were used to identify mechanism of FP IC/C. According to these clients, 81 percent of midwives conducted a counselling prior to contraceptive service and only 63 percent were using DMT for FP for IC/C. Although most of the client received counselling, the counselling was not yet appropriate, because it was not accordance with guiding principles, such as no privacy for clients during counselling; the stages of counselling partially implemented; some of the providers tend to direct clients to use certain contraceptive methods.
The client-providers observation show that there are several aspects of micro counselling skills that are not implemented during counselling such as: Providers not said that the information given during counselling was confidential; only 64 providers said encouragement for clients to ask when they have concerns or problems; there was no exploration of clients' need for dual protection contraceptive (preventing pregnancy and STI); only 45 percent providers make sure that clients understand the information; and only 58 percent of providers encourage clients to come back when they have questions or need explanations. Mechanism for FP IC/C should be adjusted for clients with different needs. Only 29 percent of providers asking whether returning clients had experience side effects during contraceptive use.

In terms of clients' acceptance, 98 percent of clients were satisfied with FP IC/C delivered by providers, and almost all the clients said that they will be back to the health center for FP services. Client satisfaction is associated with effective method use, method continuation and positive conversation, 69 percent of clients said that they will suggest others to received FP services at the same health center they use contraception.

In terms of knowledge of contraceptive methods, injectable and pill are the most known modern methods in both clients who received FP ICC and clients who did not received any counselling. In all methods, knowledge of contraception in client who received FP IC/C were higher than those who were not. The percent differences were multiple times (Figure 1).

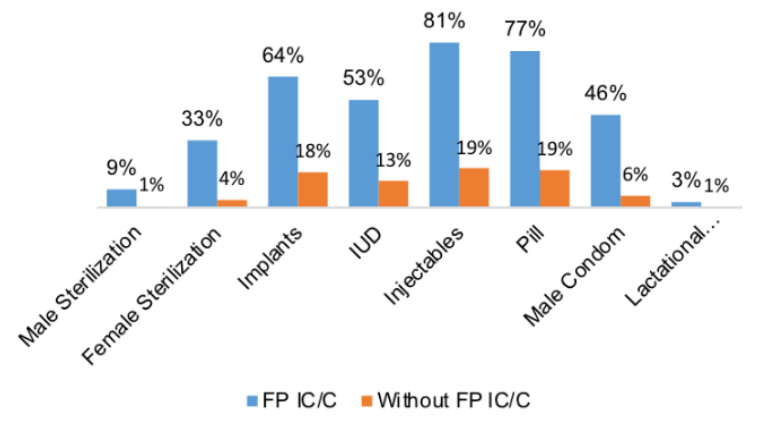

Figure 1. Knowledge of Contraceptive Methods by Family Planning IC/C Reception

Figure 2 shows that there are differences in knowledge of contraceptive methods between clients who received FP IC/C using DMT and those who received counselling using other tools. It it seen that clients who receive FP IC/C using DMT have a higher knowledge than those who received counselling using other tool. 


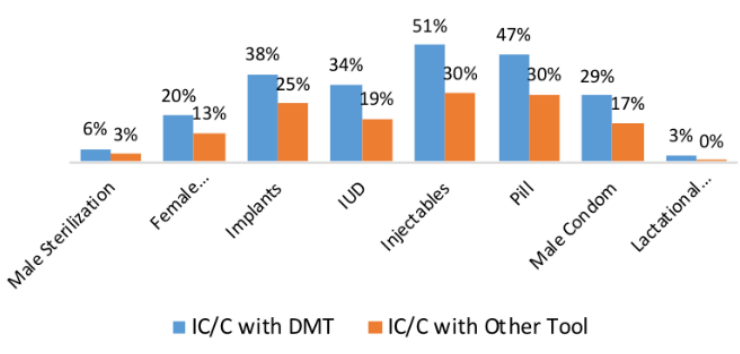

Figure 2. Knowledge of Contraceptive Methods by Usage of Family Planning DMT

Regarding clients' attitude, information obtained from clients who are using contraception during data collection. Client were asked the duration of future use of contraception, generally both clients who received FP IC/C and those who were not, want to continue using contraception until they were menopause or could not get pregnant anymore. However, clients who received FP IC/C have higher percentage those who are not.

In the use of contraceptive methods, both clients have a higher prevalence in contraceptive use (more than 90 percent). However, those who were not received FP IC/C had a higher percentage of not using any contraceptive during data collection than those who received FP IC/C, six percent compare with three percent.

\section{Discussion}

Research shows that poor family planning counselling is associated with discontinuation and method failure. One study by Keller demonstrated a strong relationship between reception of accurate information about methods, including anticipated side effects, and the tendency of clients to continue with methods and to resist negative rumors [13]. Study in Bogota, compares women who bought oral contraceptives from pharmacist or non-family planning facilities (self-subscribers) with those who received pills from physicians (private or FP facilities). Twice as many self-subscribers reported side effects than those obtaining orals from physicians. Lacking a reference point for medical review, almost two-thirds of self-subscribers than among the users of facilities based services. This translated into slightly greater discontinuation rates among selfsubscribers than among facility based services [14].

Informed choice remains the guiding principle, clients who already have a method preference should be given that method after screening and counselling, unless it is inappropriate for medical or personal reason [15]. The result of this study found some of the providers tend to direct clients to use certain contraceptive methods, whereas it should be recognize that there is no single method good for all clients. There is great difference in what clients and their partners find essential, attractive, inconvenient, or intolerable about contraceptive methods. Research shows that clients who receive the method they came for are significantly more likely to continue using method than those who do not receive their preferred method [16].

According to Murphy and Steele good client-provider interaction depends not only on the exchange of accurate information, but also on a process that creates an atmosphere of trust and allows sharing between the provider and client [17]. The curriculum on IC/C using DMT for FP training suggests that three micro skills underlie this family planning counselling to be effective are observing and developing good relationship skills; effective listening and asking skills; helping carry out client's decision skills [18].

The findings of the current study suggest that midwives' micro skills are not quite adequate, there are several important aspects of the micro skills that were not perform by selected midwives. Inadequate communication between service providers and patients may impact the disclosure or understanding of salient information concerning the appropriate use and side effects of various contraceptive, which may in turn lead to contraceptive discontinuation [19]. One of micro skills aspects that poorly performed are assure clients that all information will be kept confidential, while such encouragement will create an atmosphere of trust and associated with positive outcome.

Another micro skill that poorly implemented was encourage clients to ask follow up questions about side effects or to clarify instructions. One Africa study found that women who receive inadequate counselling about side effects are more likely to become family planning dropouts when they experience side effects [20]. If methods like IUDs and implants are not explained sufficiently and their potential side effects appreciated, users are much more likely to discontinue use [21].

Another aspect of micro skills that was not implemented was make sure that client understand the information given during IC/C. Some midwives tend to make counselling a one-way activity, midwives talked at length about each available method and the asked client to choose one and almost never checked to see if the client understood the information given. In one study, the consequences of misinformation had made 26 to 60 percent of users stopped taking the pill because they worried about its safety [22].

A client may be in a certain stage or situation in life that requires special attention from provider, with the rising prevalence of sexually transmitted infections such as HIV, risk assessment and prevention messages related to STDs and HIV are becoming an integral part of FP IC/C. This current study found that there was no exploration of clients' need for dual protection contraceptive (preventing pregnancy and STDs). Clients who are at risk need special encouragement, skills and support to use condoms in addition any other method selected.

This study showed that FP IC/C had a positive effect on clients' knowledge and practice of FP. Knowledge of contraceptive methods were far higher in those who received FP IC/C than those who were not. Study in Mansoura, Egypt found a significant improvement in couples' knowledge and practice following counselling. Their awareness of FP increased, such as the purpose, benefits and side effects of each method [23].

During the counselling session a tool can help client understand key information while also reminding provider to discuss important points. This study reveal that the using of DMT for family planning can effect differences in clients' knowledge of contraceptive methods. In fact, clients who received counselling using DMT have higher 
[9] Lerman C, Molyneaux JW, Moeljodihardjo S, Pandjaitan S. The correlation between family planning program inputs and contraceptive use in

knowledge of contraceptive method. Evidence of the importance providing written as well as oral information comes from a study by the Program Appropriate Technology in Health (PATH) The data indicate date most people remember messages better if the spoken word is reinforced by written or pictorial messages [24].

\section{CONCLUSION}

The current study assessed the provision of family planning counselling services in selected health center in two provinces, South Sumatera and West Kalimantan. Overall, the results showed that trained midwives always perform FP IC/C prior to contraceptive use. Still, the quality of the counselling is weak due to several aspects of micro counselling skills are not implemented and the counselling was not accordance with key principles of FP ICC. Hopefully, these results can be utilized by family planning policy-makers to further develop family planning services in Indonesia.

\section{ACKNOWLEDGMENT}

We would like to show our gratitude to our senior colleagues T.Y Prihyugiarto, MSPH and Dra Hadriah Oesman, MS who provided insight and expertise that greatly assisted the research and for sharing their wisdom with us during this research.

\section{REFERENCES}

[1] Peraturan Menteri Kesehatan Republik Indonesia nomor 97 tahun 2014 tentang Pelayanan Kesehatan Masa Sebelum Hamil, Masa Hamil, Persalinan, dan Masa Sesudah Melahirkan, Penyelenggaraan Pelayanan Kontrasepsi, serta Pelayanan Kesehatan Seksual, Pasal 20.

[2] Badan Kependudukan dan Keluarga Berencana Nasional. Modul komunikasi inter personal/konseling. Jakarta: BKKBN; 2013.

[3] Badan Koordinasi Keluarga Berencana Nasional. Alat bantu pengambilan keputusan ber-KB: alat bantu pengambilan keputusan ber-KB dan pedoman bagi klien dan bidan edisi ketujuh. Jakarta: BKKBN; 2011

[4] National Population and Family Planning Board (BKKBN), Statistics Indonesia (BPS), Ministry of Health (Kemenkes), and ICF. Indonesia Demographic and Health Survey 2017. Jakarta: BKKBN, BPS, Kemenkes and ICF; 2018

[5] The ACQUIRE Project. Counselling for effective use of family planning: trainer's manual. New York: EngenderHealth/The ACQUIRE Project; 2008.

[6] World Health Organization Department of Reproductive Health and Research (WHO/RHR) and Johns Hopkins Bloomberg School of Public Health/Center for Communication Programs (CCP), Knowledge for Health Project. Family planning: a global handbook for providers $(2018$ update). Baltimore and Geneva: CCP and WHO; 2018.

[7] Molyneaux JW, Paul JG.The impact of targeted family planning programs in Indonesia. Population and Development Review. 2000; 26:61-85.

[8] Angeles G, Guilkey DK, Mroz TA. The effects of education and family planning programs on fertility in Indonesia. Economic Development and Cultural Change. 2005; 54 (1): 165-201.

$$
\text { (1): 26-37. }
$$

[10] Bruce J. Fundamental elements of the quality of care: a simple framework. Studies in family planning. 1990; 20 (4):150-155.

[11] Undang-Undang Republik Indonesia Nomor 52 Tahun 2009 tentang Perkembangan Kependudukan dan Pembangunan Keluarga.

[12] Peraturan Pemerintah Republik Indonesia Nomor 61 Tahun 2014 tentang Kesehatan Reproduksi

[13] Keller AB. Patient attrition in five Mexico City family planning clinics. Clinics, Contraception, and Communication. Des Moines: Meredith Corporation. 1973; 25-50.

[14] Measham AR. Self-subscription of oral contraceptives in Bogota $_{2}$ Colombia.
Contraception. 1976; 13(3): 333-340.

[15] Murphy. E, Steele C. Client-provider interactions in family planning services: guidance from research and program experience. Maximizing Access and Quality Paper. 2000; 1(2).

[16] Huezo C, Malhorta U. Choice and user continuation of methods of contraception: a multicenter study. London: International Planned Parenthood Federation; 1993.

[17] Murphy E, Steele C. Client-provider interactions in family planning services: guidance from research and program experience. Maximizing Access and Quality Paper. 2000; 1(2).

[18] Badan Kependudukan dan Keluarga Berencana Nasional. Modul Diklat Teknis Penggunaan Alat Bantu Pengambilan Keputusan (ABPK) dalam KIP/Konseling KB. Jakarta: BKKKBN; 2015

[19] Okour MA, Saadeh RA, Zaquol M. Evaluation of family planning counselling in North Jordan. Sultan Qaboos University Medical Journal. 2017; 17(4): 436-443.

[20] Cotten N. early discontinuation of contraceptive use in Niger and the Gambia. International Family Planning Perspective. 1992; 18 (4): 145149.

[21] Berelson, B. Presedent message. Population Council Annual Report. New York: The Population Council; 1966.

[22] Grubb GS. Women's perception of the safety of the pill: a survey in eight developing countries. Report of the Perception of the Pill Survey Groups. Journal of Biosocial Science, 1987; 19 (3):313-321.

[23] Soliman MH. Impact of antenal counselling on couples' knowledge and practice of contraception in Mansoura, Egypt. La Revue de Sante de la Mediterranee orientale. 1999; 5 (5): 1002-1013.

[24] Haffey J, Zimmerman ML, Perkin GW. Communicating contraception. Populi. 1984; 11(2):35. 